\title{
Environmental Study on a Coastal River of Bangladesh with Reference to Irrigation Water Quality Assessment: A Case Study on Shailmari River, Khulna
}

\author{
Md. Muhyminul Islam 1*, Abul Kalam Azad2, Mosummath Hosna Ara ${ }^{3}$, Masudur Rahman², \\ Nazia Hassan ${ }^{2}$, Sadhon Chandra Swarnokar ${ }^{2}$, Israth Rabeya ${ }^{2}$ \\ ${ }^{1}$ Tropical Hydrogeology and Environmental Engineering (TropHEE), Technische Universitaet Darmstadt, Darmstadt, Germany \\ ${ }^{2}$ Environmental Science Discipline, Khulna University, Khulna, Bangladesh \\ ${ }^{3}$ Chemistry Discipline, Khulna University, Khulna, Bangladesh \\ Email: ^muhyminu124@gmail.com, azad_ku@yahoo.com, hosnaara1@gmail.com,gkm.buet@gmail.com,munnazia_ku@yahoo.com, \\ skswarnokar.es10@gmail.com, ishrat.es11@gmail.com
}

How to cite this paper: Islam, M.M., Azad, A.K., Ara, M.H. Rahman, M., Hassan, N., Swarnokar, S.C. and Rabeya, I. (2016) Environmental Study on a Coastal River of Bangladesh with Reference to Irrigation Water Quality Assessment: A Case Study on Shailmari River, Khulna. Journal of Geoscience and Environment Protection, 4, 4164.

http://dx.doi.org/10.4236/gep.2016.410003

Received: September 18, 2016

Accepted: October 23, 2016

Published: October 26, 2016

Copyright $\odot 2016$ by authors and Scientific Research Publishing Inc. This work is licensed under the Creative Commons Attribution International License (CC BY 4.0).

http://creativecommons.org/licenses/by/4.0/

\section{(c) (i) Open Access}

\section{Abstract}

Water quality is the critical environmental determinant that influences the agricultural production and therefore, the economy that solely depends on its agricultural productions. Batiaghata Upazilla is one of the major crop productive areas of Khulna region and the agricultural production here largely depends on the natural water of the Shailmari River system around it. The present study was conducted to assess the suitability of this coastal river water for irrigational use. 66 water samples were collected during this study in three consecutive agricultural seasons, viz., pre-monsoon (22), monsoon (22) and post-monsoon (22) from 11 sampling stations within the river system considering the high (11) and ebb (11) tides for each station. Standard methods were followed throughout the study period for the collection of the samples and analysis of major physicochemical parameters (pH, EC, TDS, salinity, $\mathrm{Na}, \mathrm{K}, \mathrm{Ca}$, $\mathrm{Mg}, \mathrm{Cl}, \mathrm{HCO}_{3}, \mathrm{SO}_{4}, \mathrm{NO}_{3}$ and $\mathrm{PO}_{4}$ ). Hydrocehmical characterization using Piper trilinear diagram shows that the water of the river system is $\mathrm{Na}-\mathrm{Cl}$ dominated saline water type in pre-monsoon, whilst most of the samples of the river and the connected channel are characterized as fresh water of $\mathrm{Ca}-\mathrm{Mg}-\mathrm{Na}-\mathrm{HCO}_{3}$ and $\mathrm{Ca}-\mathrm{Na}-\mathrm{Mg}-$ $\mathrm{HCO}_{3}$ types in monsoon and post-monsoon respectively. The calculated values of chemical indices like SAR, \%Na, KI, PI and $\mathrm{MH}$ using the results of the analysed parameters indicate that the river water is chemically unsuitable for use in irrigation during pre-monsoon, while in the monsoon and post-monsoon the river water is within good to permissible limit for the use in the agricultural fields. However, 
high \% $\mathrm{Na}$, KI and $\mathrm{MH}$ values with high salinity of the channel water limit its use in agricultural applications in monsoon and post-monsoon. The USSL (United States Salinity Laboratory) diagram depicts that the river water is C4-S4 type with very high salinity and sodium content in pre-monsoon, while in other seasons the water is mostly C1-S1, C2-S1 or C2-S2 types (low to moderate salinity and sodium) in the river. Wilcox diagram shows that the river water is "suitable" for irrigation during monsoon and post-monsoon as the most of the samples range within "Excellent to Good" and "Good to permissible" categories, while it is "unsuitable" for crop irrigation during pre-monsoon when SAR (Sodium Adsorption Ratio) and EC (Electrical Conductivity) values of the water reach to their peaks.

\section{Keywords}

Coastal River, Irrigation, Suitability, Salinity, SAR, \% Na, FAO, Piper, USSL, Shailmari, Khulna

\section{Introduction}

Being the prime mover of life on earth, water plays a vital role in sustaining the human race, socio-economic development and the endurance of ecosystem from the medieval time [1]. The quantity and quality of water supply system is eminently indispensable for irrigation scheme, as it is considered to be one of cardinal demands and benefactors in world economy [2]. Researches on irrigation water quality and its response on soils and agriculture around the world agree that irrigation water straightly supremacies the quality of soil and the crops grown on that soil [3]-[5]. The escalating demand of agricultural land and products as a function of population growth from the past century has created disparaging situation for water resources, particularly by unplanned and haphazard industrialization and urban sprawl accompanied by diminishing resource over extraction [2]. Besides, salinization of the surface water has emerged as the limiting factor in agriculture that depends on application of irrigation water. Worldwide irrigation and agricultural production is being threatened by salinization phenomena, where around 10 million hectares of agricultural land is lost annually [6] [7]. Consequential stresses have been intricate on the quantity and quality of surface water as a result of over consumption to their capacity and pollution to such level that excludes direct human consumption or even the agricultural irrigation [4]. Elevated concentrations of various ions in irrigation waters either from the interactions within the natural geological formations or from different major anthropological activities (sewage disposal, agricultural application, industrial effluents, etc.) are deteriorating the quality of irrigational water as well as destroying agricultural crops fed by such waters or soil mass [3] [4] [8]. Being an irrigated-agriculture based country, Bangladesh depends on adequate water supply from both groundwater $(80.60 \%)$ and surface water $(19.40 \%)$ of usable quality [9]-[11]. Bangladesh possesses around 5,049,785 ha land area under irrigation, which needs intended quality water for safeguarding the growth and yield of 
crops producing in it [2] [12]. Usually surface water is been trusted by farmers as a prime source of irrigation due to its availability and cost effectiveness for irrigation purposes which has been threatened in many ways additionally with the upward withdrawal of fresh water in upstream in the dry period and subsequent encroachment of saline water towards the inland from the Bay of Bengal during this period [13] [14]. Batiaghata is one of the most populated upazillas of Khulna district and is a major agricultural production area of the south-west coastal part of the country where saline water intrusion is the most severe [15] [16]. Agriculture is well practiced in this area all through the year in different scale. Rice cultivation besides shrimp farming is very commonly seen in this part of the country. A single rice crop is cultivated in wet season by mainly harvesting the rain water as ground water irrigation as a single source of irrigation imposes a persistent threat with possibility of salinity intrusion from coastal rivers into the groundwater [15]-[17]. The situation becomes worse when monsoon precipitation is delayed due to prolonged dry period and it is a matter of issue to choose the secured source of water for irrigation [17]. Therefore, appointing befitting irrigation water source which could guarantee the safe and required amount of crop production throughout the year is of prime concern in this locality. Studies on the water quality of the groundwater and Rupsha-Kazibacha River systems around Batiaghata have already been done, but information regarding the irrigation water quality of the Shailmari River system, which passes through this upazilla and supports the irrigation based agriculture of the area, is vague [11] [16]. A detailed investigation regarding hazard identification and irrigation water quality assessment of Shailmari River could be a very authentic study to support the cramping irrigational pattern of this area and safeguard sustainability of agricultural land for future generation that would serve the local and national economy in turn.

\section{Materials and Methods}

\subsection{Study Area}

The present study was conducted on the Shailmari River system which is located in the South-west part of Bangladesh and flows through Btiaghata Upazilla of Khulna. Starting from the Rupsha-Kazibacha River, it flows over Batiaghata and falls into to the Shalta-Bhadra River. The rived is fed by a connected channel carrying was hout from the municipality and is controlled by a regulator constructed near the KoyaGhat to restrict the frequent entry of the tidal water into it aiming to preserve the monsoon fresh water for dry period irrigation. The entire river system is confined between the longitude $89^{\circ} 31^{\prime} 18.6^{\prime \prime}$ and $89^{\circ} 28^{\prime} 31.9^{\prime \prime}$ East and the latitude $22^{\circ} 44^{\prime} 45.1^{\prime \prime}$ and $22^{\circ} 46^{\prime} 23.8^{\prime \prime}$ North (Figure 1). The study area falls under sub-tropical, humid climatic region and experiences hot summer (pre-monsoon) from March to May, while receives heavy precipitation ( $80 \%$ of total annual rainfall) during monsoon lasting from June to September. The post-monsoon (October-November) is characterised by lesser precipitation with tropical cyclonic events in the coastal parts of the country [12]. Ganges deltaic deposits with deltaic silt deposits and mangrove swamp deposits of late Holocene to recent age 


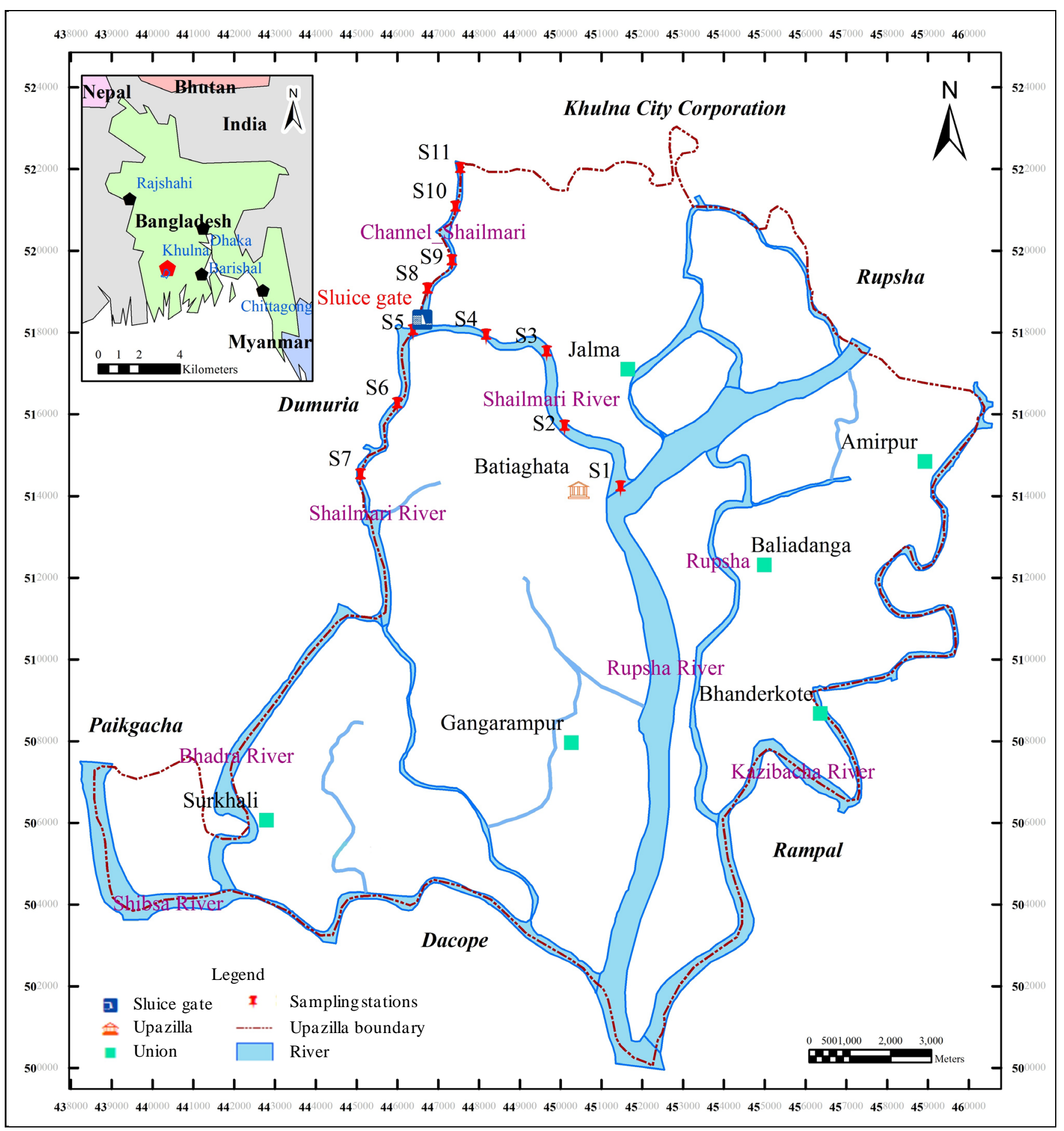

Figure 1. Location of the sampling stations in the study area.

formed the surface lithology of the study area [18] [19]. The river basin is highly characterised by extensive agricultural farming, fish farming, livestock, poultry industries, brick manufacturing and other industries. Domestic sewage and wastewater generating from the commercial sites and industries is thrown-off into the river system directly 
without pre-treatment. Being the coastal river, River Shailmari and its adjacent channels face diurnal tidal fluctuation that allows sea water mixing with the fresh water flowing the upstream. The complex coastal climatic pattern with the local geologic and anthropogenic structure of the area controls the hydro chemical behaviour of the river system in this coastal region.

\subsection{Sampling, Preservation, and Preparation}

Prior selecting the water sampling sites from a well-studied reconnaissance survey, samples were collected from 11 sampling stations based on the characterizing features of the locations along the river. Coordinates of the sampling stations were extracted in the field by using a GARMIN Geographic Positioning System (GPS) device. Samples were collected from the midstream of the river by using an engine boat and following the guidelines of standard methods [20]. Samples for cationic and anionic analyses were collected in separate $500 \mathrm{ml}$ PET bottles and cationic samples were preserved by adding $\mathrm{HCl}$ (to $\mathrm{pH} \sim 2$ ). Then samples were carried to the laboratory and preserved at $4^{\circ} \mathrm{C}$ prior to laboratory analysis [20] [21]. Following the aforesaid procedures samples were collected for three agricultural seasons namely Pre-monsoon (May, 2014), Monsoon (August, 2014) and Post-monsoon (October, 2014) from the similar stations throughout the study period. Tidal cycles were considered carefully and therefore, 22 samples were collected during each sampling seasons considering both of high and low tides for each station. The number of samples in total was 66 . The names and numbers of eleven sampling stations with typical scenario and station ID are listed in Table 1.

\subsection{In-Situ and Laboratory Measurements}

Physical parameters- pH, Dissolved Oxygen (DO), Total Dissolved Solid (TDS), and

Table 1. Location, sample ID and salient features of the sampling stations.

\begin{tabular}{|c|c|c|c|c|c|}
\hline \multirow{2}{*}{ Station No. } & \multirow{2}{*}{ Sample ID } & \multirow{2}{*}{ River system } & \multirow{2}{*}{ Dominant features of the station } & \multicolumn{2}{|c|}{ Coordinates } \\
\hline & & & & Longitude $(\mathrm{N})$ & Latitude (E) \\
\hline 01 & S1HT, S1LT ${ }^{*}$ & River & Agriculture, Commercial, Fish farms & $89^{\circ} 31^{\prime} 18.6^{\prime \prime}$ & $22^{\circ} 44^{\prime} 30.9^{\prime \prime}$ \\
\hline 02 & S2HT, S2LT & River & Agriculture, Fish farms, Domestic & $89^{\circ} 30^{\prime} 38.6^{\prime \prime}$ & $22^{\circ} 44^{\prime} 55.9^{\prime \prime}$ \\
\hline 03 & S3HT, S3LT & River & Agriculture, Fish farms & $89^{\circ} 30^{\prime} 22.8^{\prime \prime}$ & $22^{\circ} 44^{\prime} 13.4^{\prime \prime}$ \\
\hline 04 & S4HT, S4LT & River & Agriculture, Brick field & $89^{\circ} 30^{\prime} 22.8^{\prime \prime}$ & $22^{\circ} 44^{\prime} 39.9^{\prime \prime}$ \\
\hline 05 & S5HT, S5LT & River & Agriculture, Grave yard, Fish farms & $89^{\circ} 30^{\prime} 20.3^{\prime \prime}$ & $22^{\circ} 44^{\prime} 04.6^{\prime \prime}$ \\
\hline 06 & S6HT, S6LT & River & Agriculture, Fish farms & $89^{\circ} 29^{\prime} 53.5^{\prime \prime}$ & $22^{\circ} 44^{\prime} 04.8^{\prime \prime}$ \\
\hline 07 & S7HT, S7LT & River & Agriculture, Food industry & $89^{\circ} 28^{\prime} 41.1^{\prime \prime}$ & $22^{\circ} 46^{\prime} 10.7^{\prime \prime}$ \\
\hline 08 & S8HT, S8LT & Channel & Domestic, Agriculture, Brick field & $89^{\circ} 28^{\prime} 15.6^{\prime \prime}$ & $22^{\circ} 46^{\prime} 08.6^{\prime \prime}$ \\
\hline 09 & S9HT, S9LT & Channel & Domestic, Agriculture, Brick field & $89^{\circ} 28^{\prime} 38.8^{\prime \prime}$ & $22^{\circ} 46^{\prime} 47.2^{\prime \prime}$ \\
\hline 10 & S10HT, S10LT & Channel & Domestic, Commercial, Industries & $89^{\circ} 28^{\prime} 43.9^{\prime \prime}$ & $22^{\circ} 46^{\prime} 47.6^{\prime \prime}$ \\
\hline 11 & S11HT, S11LT & Channel & Domestic, Agriculture, Brick field & $89^{\circ} 28^{\prime} 31.9^{\prime \prime}$ & $22^{\circ} 46^{\prime} 23.8^{\prime \prime}$ \\
\hline
\end{tabular}

Note: $\mathrm{HT}=$ High Tide, $\mathrm{LT}=$ Low Tide. 
Electrical Conductivity (EC) were measured in-situ using portable $\mathrm{pH}$ meter, DO meter (HACH sensION156 portable) and EC/TDS meter (HANNA H1-9635) after calibration [20]. All other major ions $\left(\mathrm{Na}^{+}, \mathrm{K}^{+}, \mathrm{Ca}^{2+}, \mathrm{Mg}^{2+}, \mathrm{HCO}_{3}^{-}, \mathrm{Cl}^{-}, \mathrm{NO}_{3}^{-}, \mathrm{SO}_{4}^{2-}\right.$ and $\mathrm{PO}_{4}^{3-}$ ) were analysed following the standard procedures [20] [22]. $\mathrm{HCO}_{3}^{-}$was determined tritimetrically with $\mathrm{HCl}$ at the sampling sites using methyl orange indicator.Sodium $\left(\mathrm{Na}^{+}\right)$and potassium $\left(\mathrm{K}^{+}\right)$were measured using GENWAY flame photometer (Model No. PEP 7 and PEP 7/C). Tritimetric methods were used for determining calcium $\left(\mathrm{Ca}^{2+}\right)$, magnesium $\left(\mathrm{Mg}^{2+}\right)$ and chloride $\left(\mathrm{Cl}^{-}\right)$[20] [22]. UV-visible spectrophotometer was used to detect sulphate $\left(\mathrm{SO}_{4}^{2-}\right)$, ortho-phosphate $\left(\mathrm{PO}_{4}^{3-}\right)$ and nitrate $\left(\mathrm{NO}_{3}^{-}\right)$in the water samples [20]. Replicate analysis of blank, standards and water samples were performed during the study to achieve the precision and accuracy and kept within $\pm 5 \%$ by repeatative anlysis after calculating the ionic balance errors [23] [24].

\subsection{Water Quality Indices and Classification Methods}

Different water quality parameters like Total Hardness (TH) [25], TDS classes [26] [27] were used in the study to assess the quality of the water. In agriculture, water quality is an important criterion for the development of a successful and sustainable irrigation scheme. In order to assess the suitability of the river water for irrigation use, various parameters like percentage of sodium (Na\%), sodium absorption ratio (SAR), residual sodium carbonate (RSC), permeability index (P.I.), Kelly's index (KI), Magnesium Hazard $(\mathrm{MH})$ were used in the study using the mentioned equations in Table 2 [11] [28] [29]. $\mathrm{Na} \%$ is a measure of salinity hazard in water and together with EC is useful in classifying the irrigation water [5]. SAR expresses the sodium or alkali hazard in irrigation water and quantifies the relative proportions of sodium to calcium and magnesium [4]. The amount of bicarbonate and carbonate in excess of alkaline earth metals (Ca and $\mathrm{Mg}$ ) also affects the irrigation water quality and is quantified by calculating the residual sodium carbonate (RSC) content of the water [30]. Permeability of the soil depends also on the quality of the irrigation water and permeability index (PI) classifies

Table 2. Common indices for irrigation water quality evaluation.

\begin{tabular}{cc}
\hline Sl. no. & Water quality indices \\
\hline 1 & Total Hardness $\left(\right.$ as $\left.\mathrm{CaCO}_{3}\right)=\left(\mathrm{Ca}^{2+}+\mathrm{Mg}^{2+}\right) \times 50$ \\
2 & $\mathrm{SAR}=\mathrm{Na}^{+} / \sqrt{\left(\left(\mathrm{Ca}^{2+}+\mathrm{Mg}^{2+}\right) / 2\right)}$ \\
3 & $\mathrm{Na} \%=\left(\left(\mathrm{Na}^{+}+\mathrm{K}^{+}\right) \times 100\right) /\left(\mathrm{Ca}^{2+}+\mathrm{Mg}^{2+}+\mathrm{Na}^{+}+\mathrm{K}^{+}\right)$ \\
4 & $\mathrm{RSC}=\left(\mathrm{HCO}_{3}^{-}+\mathrm{CO}_{3}^{2-}\right)-\left(\mathrm{Ca}^{2+}+\mathrm{Mg}^{2+}\right)$ \\
5 & $\mathrm{PI}=\left(\left(\mathrm{Na}^{+}+\sqrt{\mathrm{HCO}_{3}^{-}}\right) \times 100\right) /\left(\mathrm{Ca}^{2+}+\mathrm{Mg}^{2+}+\mathrm{Na}^{+}\right)$ \\
7 & $\mathrm{KI}=\mathrm{Na}^{+} /\left(\mathrm{Ca}^{2+}+\mathrm{Mg}^{2+}\right)$ \\
$\mathrm{MR}=\left(\mathrm{Mg}^{2+} \times 100\right) /\left(\mathrm{Ca}^{2+}+\mathrm{Mg}^{2+}\right)$
\end{tabular}

${ }^{\star}$ For 1 , all cations and anions are expressed in $\mathrm{mg} / \mathrm{l}$ and for $2-7$, all are in meq/1. 
the water based on concentrations of sodium, calcium, magnesium and bicarbonate in the water to assess its suitability for irrigation use [29] [31]. KI is a measure of classification of the water for irrigation and sodium is measured against calcium and magnesium to calculate this parameter [5]. The excess of magnesium concentration in water is harmful for soil and affects plant growth. $\mathrm{MH}$ is used to evaluate the quality of the water based on the quantity of magnesium in the irrigation water [5] [29]. Graphical methods related to water quality classifications were used in this study to further evaluate the irrigation water quality of the river system. Piper diagram was applied to find the water classes and its dominating ions in different seasons and stations [32]. Wilcox diagram and U.S Salinity Laboratory (USSL) classifications diagram were also applied to find the seasonal variability and suitability of the river water for irrigation [8] [33].

\section{Results and Discussion}

\subsection{General Hydrochemistry and Hydrochemicalfacies}

The results showed wide hydrochemical variation among the seasons throughout the study period. Summary of the hydrochemistry of the river water are incorporated in Table 3. Large variation in elemental concentration of a parameter might affect the mean values of the single parameter. Therefore, median was also incorporated in the table to indicate the central tendency of the dataset [38]. EC was observed highest in pre-monsoon with an average of 35,300 $\mu \mathrm{S} / \mathrm{cm}$ during high tide and 33,290.91 $\mu \mathrm{S} / \mathrm{cm}$ during low tide. Lowest values of EC was observed in post-monsoon with an average of $447.18 \mu \mathrm{S} / \mathrm{cm}$ and $438.00 \mu \mathrm{S} / \mathrm{cm}$ during high and low tides respectively, while the values in monsoon were $603.82 \mu \mathrm{S} / \mathrm{cm}$ and $597.36 \mu \mathrm{S} / \mathrm{cm}$ in its consecutive high and low tides during the study period. TDS and Salinity followed the similar trend of EC and showed similar tidal variation during the study. The tidal distribution of the $\mathrm{pH}$ was likely 7.60 \pm 0.04 and $7.61 \pm 0.06,7.85 \pm 0.04$ and $7.89 \pm 0.03$, and $7.63 \pm 0.03$ and $7.71 \pm 0.07$ respectively in pre-monsoon, monsoon and post-monsoon in their respective high and low tides which indicates that the river is alkaline in nature. The maximum alkalinity in monsoon might be due to the increased weathering input into the river that carries more alkali earth metals and thus contribute to increase the alkalinity of the river water [22]. The concentrations of DO were observed $(4.61 \pm 0.58) \mathrm{mg} / \mathrm{l}$ and $(5.08 \pm 0.73)$ $\mathrm{mg} / \mathrm{l}$, in average, during the high and low tides of the river in pre-monsoon. In monsoon, DO was found maximum in concentration $(\mathrm{mg} / \mathrm{l})$ in the river and the average concentrations were $(5.82 \pm 0.42) \mathrm{mg} / \mathrm{l}$ and $(5.58 \pm 1.02) \mathrm{mg} / \mathrm{l}$ in the corresponding high and low tides. The average concentrations were $(3.04 \pm 0.56) \mathrm{mg} / \mathrm{l}$ and $(3.37 \pm$ $0.89) \mathrm{mg} / \mathrm{l}$ respectively during the high and low tides in post-monsoon which were observed lowest among the three sampling seasons within the river system during the study period. The observed average concentrations of $\mathrm{Na}^{+}$in pre-monsoon were $10,849.31 \pm 576.05$ and $9217.74 \pm 1025.58$ during high and low tides. In monsoon, the concentrations were $77.86 \pm 118.66$ and $86.06 \pm 134.99$, while in post-monsoon the ranges of average concentrations were $87.19 \pm 92.86$ and $88.66 \pm 94.65$ in respective high and low tides. The average concentrations of $\mathrm{K}^{+}$were within a range of $336.64 \pm$ 
Table 3. Statistical summary of the physico-chemical parameters of Shailmari River and its channel water in pre-monsoon, monsoon and post-monsoon.

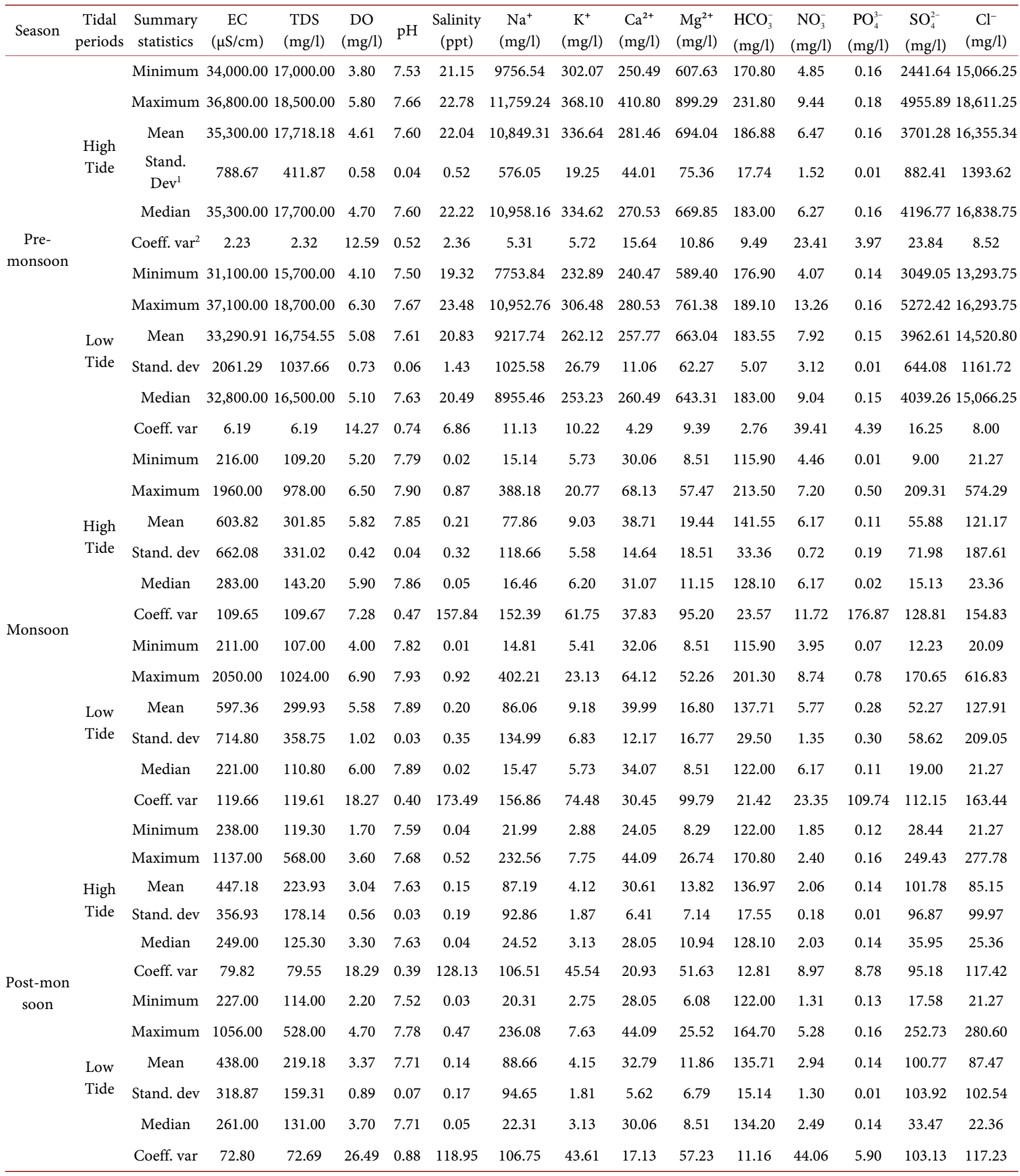

${ }^{1}$ Standard deviation, ${ }^{2}$ Coefficient of variation. 
19.25 and $262.12 \pm 26.79$ during high and low tides of pre-monsoon, while concentrations were within $9.03 \pm 5.58$ and $9.18 \pm 6.83$, and $4.12 \pm 1.87$ and $4.15 \pm 1.81$ in monsoon and post-monsoon in their respective high and low tides. Highest concentration of $\mathrm{Ca}^{2+}$ was observed in pre-monsoon $(410 \mathrm{mg} / \mathrm{l}$ in high tide and $280.53 \mathrm{mg} / \mathrm{l}$ in low tide), while the lowest was in post-monsoon $(24.05 \mathrm{mg} / \mathrm{l}$ in high tide and $28.05 \mathrm{mg} / \mathrm{l}$ in low tide). Concentrations of $\mathrm{Mg}^{2+}$ was observed higher in pre-monsoon (high tide = $694.04 \pm 75.36 \mathrm{mg} / \mathrm{l}$ and low tide $=663.04 \pm 62.27 \mathrm{mg} / \mathrm{l}$ ) comparative to monsoon (high tide $=19.44 \pm 18.51 \mathrm{mg} / \mathrm{l}$ and low tide $=16.80 \pm 16.77 \mathrm{mg} / \mathrm{l}$ ) and post-monsoon (high tide $=13.82 \pm 7.14$ and low tide $=11.86 \pm 6.79 \mathrm{mg} / \mathrm{l})$. During the study EC, TDS, salinity, $\mathrm{Na}^{+}$and $\mathrm{Mg}^{2+}$ were observed higher in pre-monsoon relative to the other sampling seasons which might be attributed to the reduced upstream freshwater inflow and simultaneous upward encroachment of sea water during this period, while heavy precipitation led to dilute the concentrations in monsoon and consecutive post-monsoon seasons in this area [13] [39].

Among the anions, concentration of $\mathrm{HCO}_{3}^{-}$was observed higher in pre-monsoon (186.88 $\pm 17.74 \mathrm{mg} / \mathrm{l}$ and $183.55 \pm 5.07 \mathrm{mg} / \mathrm{l}$ in consecutive high and low tides). In monsoon, the average concentrations were $141.55 \pm 33.36 \mathrm{mg} / \mathrm{l}$ and $137.71 \pm 29.50 \mathrm{mg} / \mathrm{l}$ respectively in high tide and low tide, while in post-monsoon average concentrations of $136.97 \pm 17.55 \mathrm{mg} / \mathrm{l}$ and $135.71 \pm 15.14 \mathrm{mg} / \mathrm{l}$ were observed in the river water following the similar tidal pattern. Variation of $\mathrm{HCO}_{3}^{-}$in the river could be attributed to the bicarbonate weathering coupled with wastewater discharges into the river during the sampling seasons [40] [41]. $\mathrm{Cl}^{-}$ion was found highest in pre-monsoon (18611.25 $\left.\mathrm{mg} / \mathrm{l}\right)$ and, while lowest was observed in monsoon (20.09 $\mathrm{mg} / \mathrm{l}$ ). Seasonal distribution (mean $\pm \mathrm{SD}$ ) of $\mathrm{Cl}^{-}$ion was respectively $16355.34 \pm 1393.62 \mathrm{mg} / \mathrm{l}$ and $14520.80 \mathrm{mg} / \mathrm{l}, 121.17 \pm$ $87.81 \mathrm{mg} / \mathrm{l}$ and $127.91 \pm 209.05 \mathrm{mg} / \mathrm{l}$, and $85.15 \pm 99.97 \mathrm{mg} / \mathrm{l}$ and $87.47 \pm 102.54 \mathrm{mg} / \mathrm{l} \mathrm{in}$ pre-monsoon, monsoon and post-monsoon in each of their successive high and low tides. $\mathrm{Cl}^{-}$, being the major constituent of sea water, indicates the influence of the sea water on the river water chemistry in the respective seasons and tidal periods during the study [42] [43]. $\mathrm{SO}_{4}^{2-}$ concentration (mg/l) varied between 2441.64 to 4955.89 (high tide) and 3049.05 to 5272.42 (low tide) in pre-monsoon, while the ranges were between 9.0 to 209.31 and 12.23 to 170.65 in monsoon and 28.44 to 249.43 and 17.58 to 252.73 in post-monsoon in their respective high and low tides. Higher load of sulfate in pre-monsoon might be coming from the wreathing and erosional deposits into the river, while the adjacent brick industries and agricultural runoff could be the possible source of additional sulfate concentrations in the river during pre-monsoon period [44]. Concentration of $\mathrm{NO}_{3}^{-}$in the river varied widely among the sampling seasons. Higher concentrations were recorded in pre-monsoon (high tide $=6.47 \pm 1.52 \mathrm{mg} / \mathrm{l}$, low tide $=7.92 \pm 3.12 \mathrm{mg} / \mathrm{l}$ ), while monsoon was moderately loaded (high tide $=6.17 \pm$ 0.72 , high tide $=5.77 \pm 1.35)$ and post-monsoon showed lowest concentration $(2.06 \pm$ $0.18 \mathrm{mg} / \mathrm{l}$ and $2.94 \pm 1.30 \mathrm{mg} / \mathrm{l}$ in high and following low tides) in each of the tidal periods. The sewage disposal, industrial effluents and agricultural runoff might be the possible sources of nitrate contamination in the river water, while de-nitrification and 
microbial consumption contributed significantly to reduce the concentration in postmonsoon [11] [44]. The concentration of $\mathrm{PO}_{4}^{3-}$, following the successive high and low tides in pre-monsoon, ranged from 0.16 to $0.18 \mathrm{mg} / \mathrm{l}$ (average $0.16 \pm 0.01 \mathrm{mg} / \mathrm{l}$ ) and 0.14 to $0.16 \mathrm{mg} / \mathrm{l}$ (average $0.15 \pm 0.01 \mathrm{mg} / \mathrm{l}$ ) in the river. During the monsoon it ranged from 0.01 to $0.50 \mathrm{mg} / \mathrm{l}$ (average $0.11 \pm 0.19 \mathrm{mg} / \mathrm{l}$ ) and 0.07 to $0.78 \mathrm{mg} / \mathrm{l}$ (average $0.28 \pm$ $0.30 \mathrm{mg} / \mathrm{l}$ ), while in post-monsoon the concentration was within 0.12 to $0.16 \mathrm{mg} / \mathrm{l}$ and 0.13 to $0.16 \mathrm{mg} / \mathrm{l}$ with an average of $(0.14 \pm 0.01) \mathrm{mg} / \mathrm{l}$ in their corresponding high and low tides.

Hardness defines the types of the water and is an important determining parameter of water for its use in different purposes. Divalent metallic cations like magnesium, calcium, strontium, ferrous iron and manganese ions are the prime movers of this hardness. Usually hardness is been classified in terms of degree of hardness as (i) soft $(<75$ $\mathrm{mg} / \mathrm{l}$ ), (ii) moderately hard (75 to $150 \mathrm{mg} / \mathrm{l}$ ), (iii) hard (150 to $300 \mathrm{mg} / \mathrm{l}$ ) and (iv) very hard (>300 mg/l) [25]. According to this classification, all of samples of the Shailmari River and the channel, irrespective of the sampling stations and tidal variations, are within the class of "very hard" as the values of $\mathrm{TH}\left(\mathrm{as} \mathrm{CaCO}_{3} \mathrm{mg} / \mathrm{l}\right)$ of the samples exceeded $300 \mathrm{mg} / \mathrm{l}$ (as $\mathrm{CaCO}_{3} \mathrm{mg} / \mathrm{l}$ ) during the dry pre-monsoon period. Spatial variation was observed in classifying hardness of water during monsoon and post-monsoon. Indicating the spatial variability in water quality, river water of Shailmari falls under the class of "moderately hard", while the regulated channel is classified as "hard" to "very hard" during monsoon and post-monsoon. The high values of TH in the river water in pre-monsoon might be due to the presence of high content of magnesium, calcium and associated ions in the river water, which reveals that saline sources together with domestic sewage disposals and industrial effluent discharges are prompting the total hardness in the Shailmari River [13] [22] [29].

Plotting of the samples on Piper trilinear diagram [32] reveals the composition of the water in different sampling seasons indicating their types (Figure 2). The diagram reveals that, in pre- monsoon the river water becomes more $\mathrm{Na}-\mathrm{Cl}$ type denoting the influence of sea-water mixing in and around the river system. Most of the samples of monsoon $(72.72 \%)$ are $\mathrm{Ca}-\mathrm{Mg}-\mathrm{Na}-\mathrm{HCO}_{3}$ type and the post-monsoon (68.18\%) water is of $\mathrm{Ca}-\mathrm{Na}-\mathrm{Mg}-\mathrm{HCO}_{3}$ type. This ascertains that, the river water receives fresh water input during these seasons and therefore the river shows temporary hardness. Rest of the samples of the monsoon and post-monsoon forming a distinct cluster shows mixed $\mathrm{Na}-\mathrm{Cl}-\mathrm{SO}_{4}$ and $\mathrm{Na}-\mathrm{Ca}-\mathrm{Cl}-\mathrm{SO}_{4}$ type, which might be representing the channel water chemistry in the respective seasons. The Schoeller diagram reveals that, $\mathrm{Na}^{+}$is the dominant cation, while $\mathrm{Cl}^{-}$is dominant among the anions in pre-monsoon (Figure 3). The mean trends of the cations and anions, regardless of the tidal variation, in the river are $\mathrm{Na}^{+}>\mathrm{Mg}^{2+}>\mathrm{Ca}^{2+}>\mathrm{K}^{+}$and $\mathrm{Cl}^{-}>\mathrm{SO}_{4}^{2-}>\mathrm{HCO}_{3}^{-}>\mathrm{NO}_{3}^{-}>\mathrm{PO}_{4}^{3-}$, respectively. In monsoon, $\mathrm{Ca}^{2+}$ dominates among the cations, while $\mathrm{HCO}_{3}^{-}$among the anions, revealing the cationic and anionic order of $\mathrm{Ca}^{2+}>\mathrm{Na}^{+}>\mathrm{Mg}^{2+}>\mathrm{K}^{+}$and $\mathrm{HCO}_{3}^{-}>\mathrm{Cl}^{-}>$ $\mathrm{SO}_{4}^{2-}>\mathrm{NO}_{3}^{-}>\mathrm{PO}_{4}^{3-}$ correspondingly. The water chemistry also reveals that the ionic patterns are likely $\mathrm{Na}^{+}>\mathrm{Ca}^{2+}>\mathrm{Mg}^{2+}>\mathrm{K}^{+}$and $\mathrm{HCO}_{3}^{-}>\mathrm{SO}_{4}^{2-}>\mathrm{Cl}^{-}>\mathrm{NO}_{3}^{-}>$ 


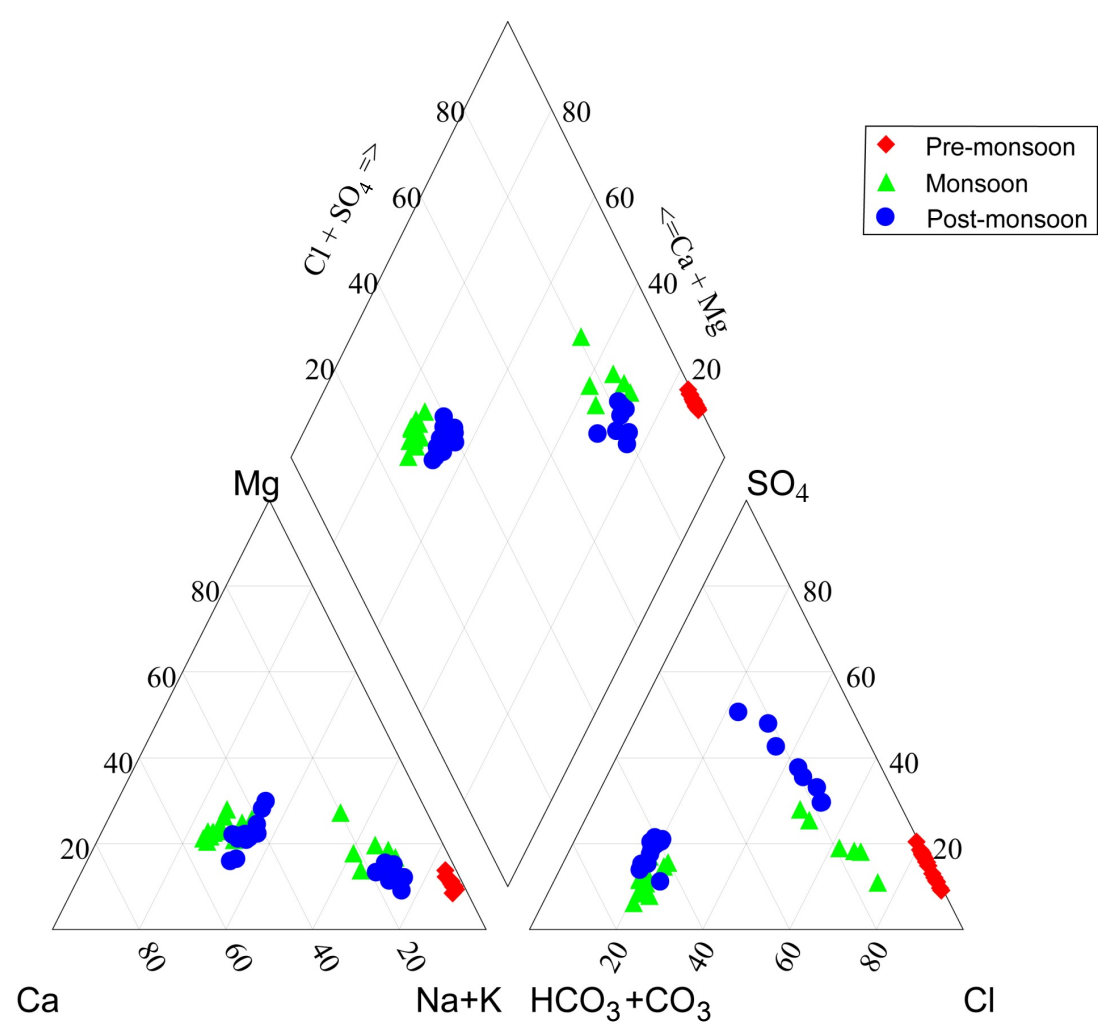

Figure 2. Piper-tri-linear diagram showing the water quality of the Shailmari River system in three sampling seasons (after Piper, 1944).

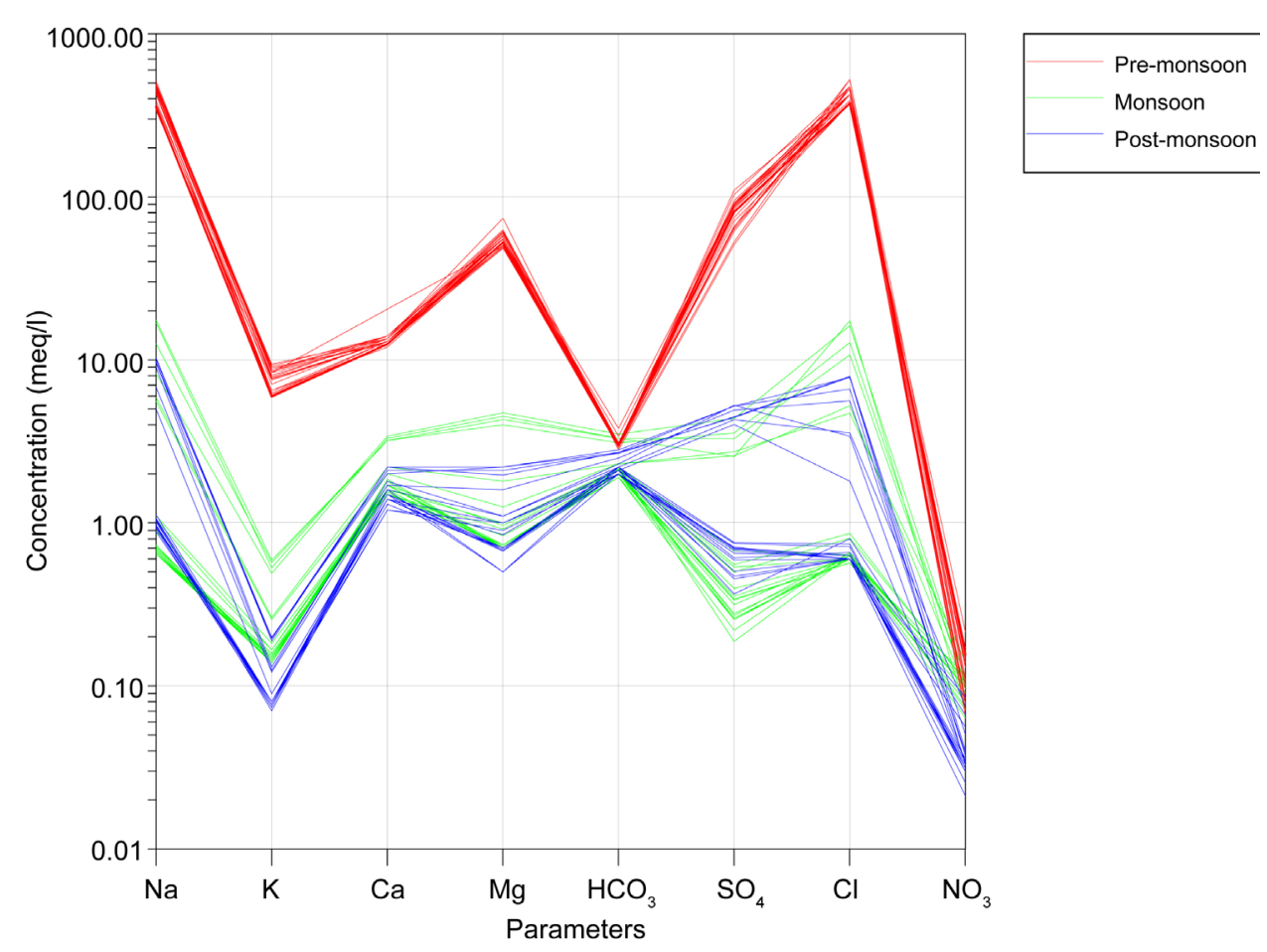

Figure 3. Loading of the major ions in three sampling seasons in the river system (after Schoeller, 1967). 
$\mathrm{PO}_{4}^{3-}$ for the cations and anions in the river system in post-monsoon (Figure 3).

\subsection{Suitability for Irrigation}

On irrigated agricultural lands, salinization is one of bountiful inauspicious environmental and human induced impacts that persuade loss of production in gigantic scale. Salinization critically limits the choice of crops, deleteriously affect crop germination and yields and can provoke soils to be inappropriate to work. It is important that all appraisal regarding irrigation water quality to be linked with the evaluation of soils to be irrigated [3]. The suitability of river water samples for irrigation use is governed by the mineral constituent present in the water. The major physico-chemical parameters, which determine the suitability of river water for irrigation are $\mathrm{pH}, \mathrm{EC}$, TDS, hardness, chloride, sulfate, carbonate, bicarbonate, nitrate, sodium, potassium, calcium, magnesium, etc. Silica, iron and boron are usually present in very minor amounts and are determined in specific circumstances, for example use of industrial waste for irrigation [45]. In assessing the suitability of waters for irrigation use, water quality characteristics that affect agricultural production need to be evaluated. Irrigational suitability of the Shailmari River and its connected channel was evaluated by calculating EC, SAR, RSC, KI, PI, MH, USSL classification, $\mathrm{Na} \%$, and Wilcox diagram. Usual and calculated parameters related to the use in irrigation are incorporated in Table 4 for 11 different stations of pre-monsoon, monsoon and post-monsoon seasons.

Electrical Conductivity (EC) is an expression of the concentration of total soluble salts in the irrigation water which is widely used for the diagnosis and classification of the water in terms of suitability for irrigation [44]. Water with EC values lower than $750 \mu \mathrm{S} / \mathrm{cm}$ is assumed to be "satisfactory" for use in irrigation, while values more than $3000 \mu \mathrm{S} / \mathrm{cm}$ makes it "unsuitable" for irrigation [45]. In the present study, according to the classification, river water is "unsuitable" for use in irrigation during pre-monsoon. In monsoon all of the samples ranges between "excellent" to "permissible" category for both of high tides and low tides, while in post-monsoon the samples are within "excellent" to "good" categories for each tides (Table 5). Total dissolved solids represents the amount of dissolved ions, minerals and other dissolved components in water and is simultaneously used with EC as an indicative of saline content of the water in absence of non-ionic dissolved constituents [46]. According to the classification described by Ayers and Westcot [3], river water in pre-monsoon is categorized as "unsuitable" for use in irrigation. In monsoon and post-monsoon the river water is within "good" to "permissible" categories which ensures their suitability for irrigation in the respective seasons (Table 5). The direct effect of high saline water (high EC) on the crops are growth rate reduction, lower yields of rice or symptoms indicating nutritional disorders under specific condition [47]. Soil degradation may also occur due to unplanned and long- term use of river water with high values of EC which may lead to crop failure in the vicinity of the irrigation area [11] [44].

If the gross level of carbonate and bicarbonate overshoots the outright amount of calcium and magnesium then water quality would be depreciated. This remnant carbo- 
Table 4. Calculated parameters to evaluate the river water for crop irrigation.

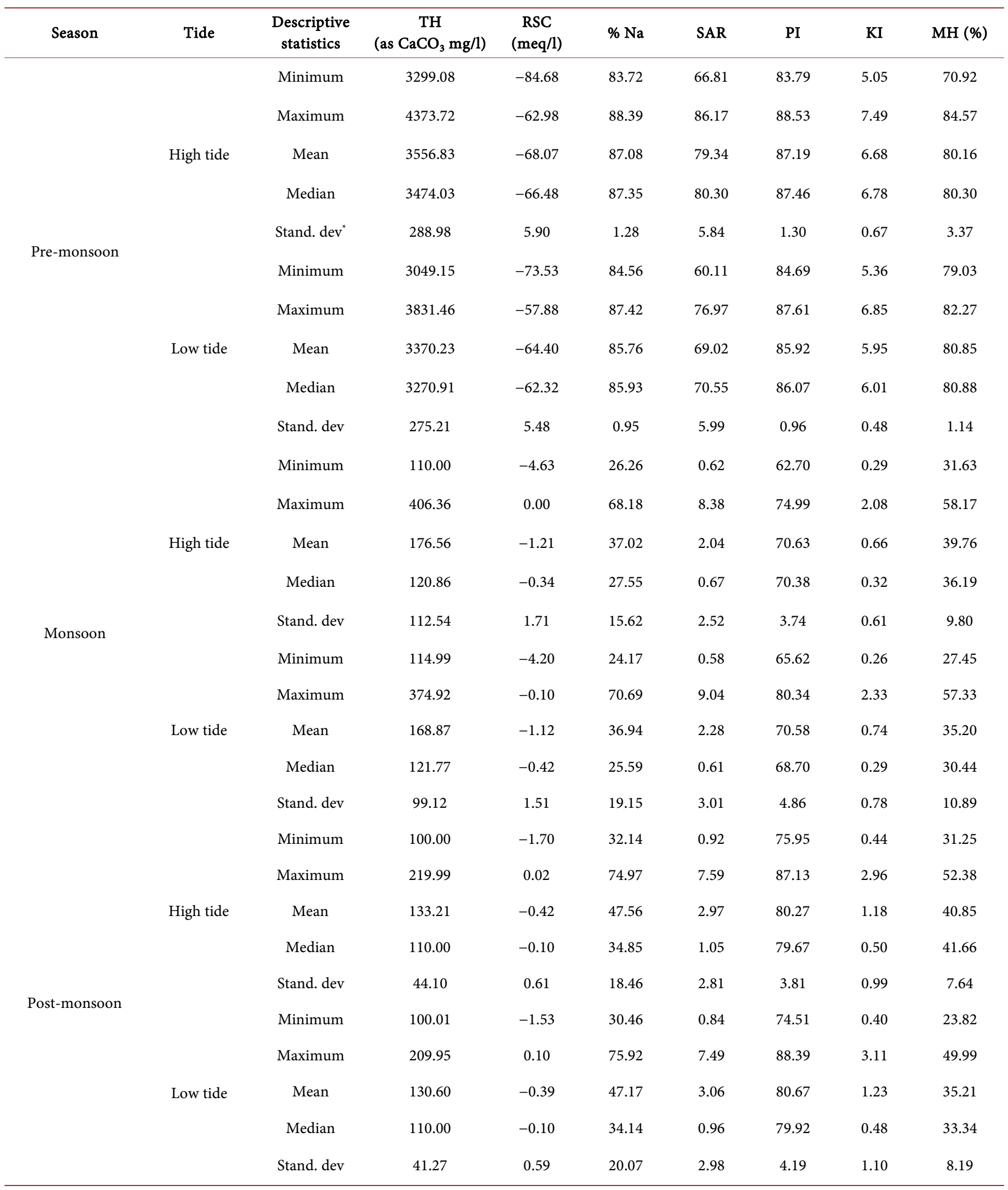

*Standard deviation. 
Table 5. Suitability analysis of the water of Shailmari River system for irrigation in different seasons.

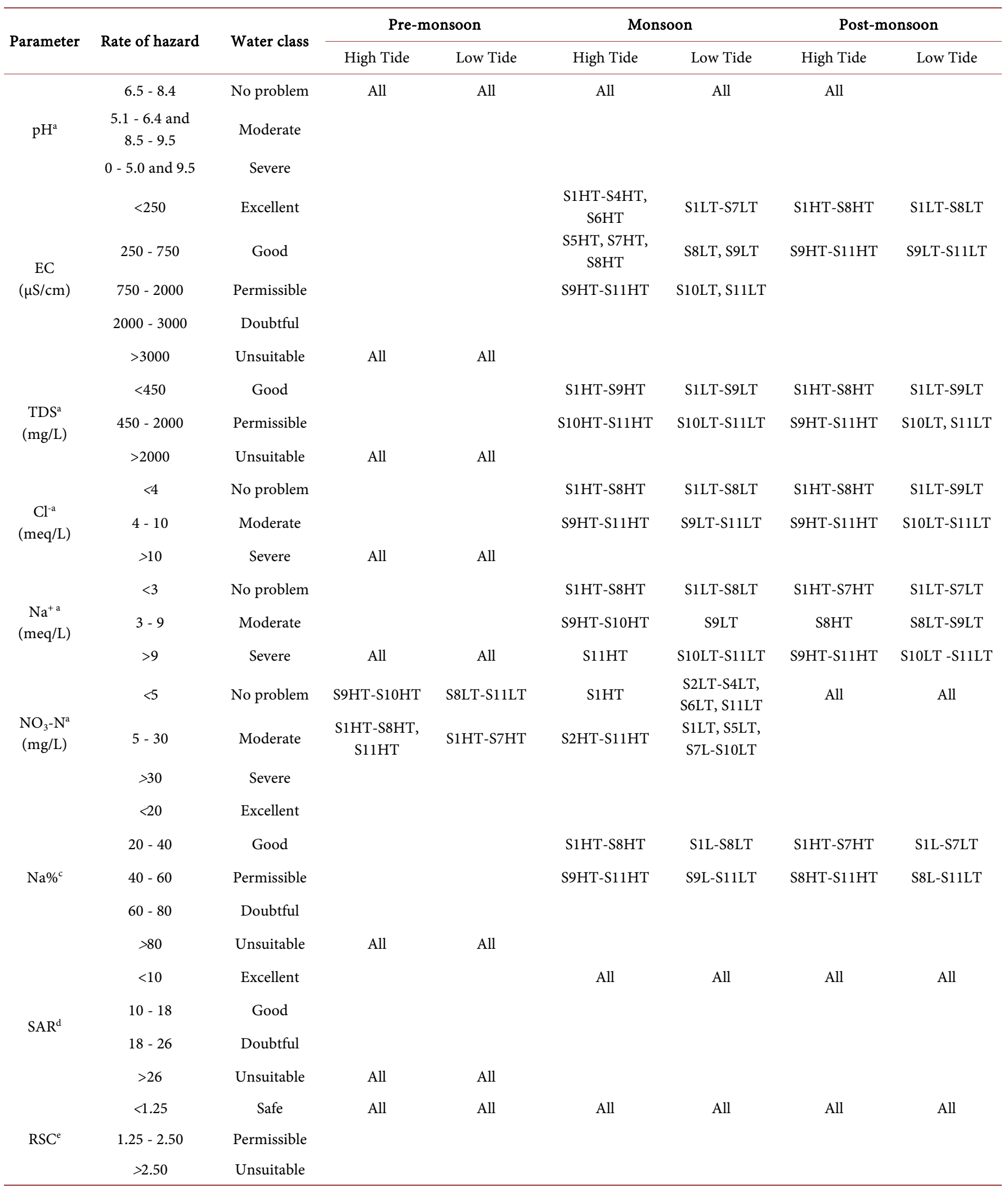

${ }^{\mathrm{a}}$ Ayers and Westcot (1994), ${ }^{\mathrm{b}}$ Raghunath (1987), ${ }^{\mathrm{C}} \mathrm{W}$ ilcox (1948), ${ }^{\mathrm{d}}$ Richards (1954), ${ }^{\mathrm{e}}$ Eaton (1950). 
nate is noted as "residual sodium carbonate" (RSC) and has been suggested by Richards [34] and Raghunath [46] both. High RSC water has high pH and if lands been irrigated with this, might cause serious infertility including accumulation of sodium carbonate which turns soil black colored [47]. Further, ongoing usage of high residual sodium carbonate waters affects crop yields. The calculated RSC value was compared with the quality classification of river water in Table 5 . In the present study, irrespective to the temporal and spatial variation, all the samples have RSC values much less than 1.25 meq/l, which reveals that all samples are of "safe" quality categories for irrigation throughout the seasons. Thereafter, the value of RSC is negative in all sampling seasons at its respective stations, indicating that there is no complete precipitation of calcium and magnesium within the river system [48].

Another limiting parameter to cognize water suitability for irrigation is sodium concentration as it can reduce the soil permeability as well as soil structure [49]-[51]. Lowsodium water could be applied for irrigation on nearly all type of soil with a little risk of developing harmful exchangeable sodium levels whereas, medium-sodium water represents a seizable sodium hazard in certain fine-textured soils, especially poorly leached soils. However, water with high-sodium content would leave significant amount of exchangeable sodium in any type of soil leading to severe soil degradation which made using this type water most difficult in the irrigation field with special soil management practice like well drainage system or use of organic matters in the field etc. [52]. In all natural waters, percent of sodium content is a common parameter to assess its suitability for agricultural purposes and at an utmost $60 \%$ sodium concentrated river water is permissible for agricultural purposes [8] [48] [51]. In the present study, values of $\% \mathrm{Na}$ of all samples varying from 83.72 to 88.39 (Table 4) in the premonsoon which indicate that the river water is "unsuitable" for use in the agricultural fields. In monsoon, $72.72 \%$ of both of high and low tidal water samples were within the "good" category whereas only $63.63 \%$ represents "good" category for the post-monsoon water samples (Table 5). Again, $27.27 \%$ of monsoon and $36.36 \%$ of the post-monsoon water samples fall within the "permissible" category. This implies that, from monsoon to post-monsoon the water of the river system lies within "good" to "permissible" categories and is, therefore, suitable for uses in the agricultural fields. The higher $\% \mathrm{Na}$ in the pre- monsoon water than in the monsoon and post-monsoon water is may be due to the input of sodium ion from increased sea water mixing in the pre-monsoon when the fresh water flow from the upstream as well as the seasonal rainfall in this part of the country remains also low [13] [53].

Together with EC, sodium adsorption ratio (SAR) is assessed to evaluate the potential infiltration problems in soils. SAR expresses the relative activity of sodium ions in exchange reactions with soil and is a measure of assessing the suitability of water for irrigation with respect to the salinity or sodium hazard [29] [48] [52]. Soil dispersion and structural damages might be occurred due to the presence of excess sodium ions in irrigation water and cause clogging and hinder infiltration by filling up many of the smaller pore spaces in finer soil particles [3] [30]. The irrigation water with a high pro- 
portion of sodium increases the exchange of sodium content of the soil replacing calcium and magnesium and affects the soil permeability making it compact and impervious which is unsuitable for seedling growth. According to Richard's [34] classification, irrespective of the tidal fluctuation, all of the river water samples of Shailmari River in the pre-monsoon fall within the "unsuitable" category with SAR values $>26$. In monsoon, SAR values ranges between 0.58 and 9.04, while in the post-monsoon it is from 0.84 to 7.59 which indicates that the river water in monsoon and post-monsoon seasons are within the excellent "category" that ensures the unconditional usability of the water in the agricultural fields (Table 5).

Chloride is present in all natural water and is an essential plant nutrient, but excess of it in the water may exhibit chloride toxicity. A concentration of $140-350 \mathrm{mg} / \mathrm{l} \mathrm{of} \mathrm{Cl}^{-}$ in water is harmful to plants, while $>350 \mathrm{mg} / \mathrm{l}$ becomes lethal to plants and shows leaf burn or drying of the leaf tissue [54]. The river water showed exceeding concentration of $\mathrm{Cl}^{-}(>350 \mathrm{mg} / \mathrm{l})$ during pre-monsoon. In monsoon and post-monsoon the concentration was within $300 \mathrm{mg} / \mathrm{l}$ for most of the samples, while only few samples of the channel showed chloride toxicity in monsoon. According to the classification of Ayers and Westcot (1985), channel water shows moderate chloride toxicity in monsoon and post monsoon (Table 5) [3]. This reveals that the river water is not suitable for use in irrigating the crops in pre-monsoon but can be used in monsoon and post-monsoon as the monsoon rainfall leaves dilution effect on the concentration of $\mathrm{Cl}^{-}$in the river system.

Long term irrigation affects the permeability of the soil and is been influenced by the total dissolved solids, sodium bicarbonate and the soil type [11] [29]. Doneen [31] classified the water for irrigation purposes in Class I, Class II, and Class III, based on a permeability index (P.I.) where Class I and Class II waters are categorized as "good" for irrigation with permeability range of $50 \%-75 \%$ or more. Class III is marked as "unsuitable" with $25 \%$ of maximum permeability. In the present study, the permeability index values range between 83.79 to 88.53 during the high tide and 84.69 to 87.61 during the low tide of per-monsoon (Table 4) which fall under the Class III indicating the maximum permeability and thus the "unsuitability" of the water for irrigation. In the monsoon, PI of the Shailmari River system ranges from 62.70 to 74.99 and 65.62 to 80.34 during the high tide and low tide respectively, while the ranges are from 75.95 to 87.13 and 74.51 to 88.39 in the post-monsoon. Accordingly, all the samples of monsoon and post-monsoon fall into the Class I and II category of Doneen's chart which reflects the "suitability" of the river water for crop cultivation during these agricultural seasons.

Kelly's index (KI) is a measure of classification of natural water for irrigation purpose. Waters with a Kelly's index $<1$ are considered as "suitable" for irrigation, while with a ratio $>1$ are "unsuitable" [36] [55]. The calculated values of KI of the Shailmari River were $>1$ in all samples of pre-monsoon (Table 4) indicating that the water is "unsuitable" for crop irrigation in pre-monsoon. In the monsoon the calculated values of KI for both of the high tide and low tide water samples range between ( 0.27 to 0.43 ) and $(0.25$ to 0.50$)$ which indicate that the values are $<1$ and the river water is "suitable" 
for irrigation. In post-monsoon, irrespective of the tidal variation, KI values of the river water samples were $<1$ indicting their suitability for irrigation. However, variation in KI indices are visible between the river and its adjacent channel as samples of the connected channel in monsoon (S9HT-S11HT; S9LT-S11LT) and post-monsoon (S8HTS11HT and S8LT-S11LT) exceed the permissible limit of 1.0 (Table 4) indicating that water of this regulated channel is "unsuitable" for use in agricultural activities during these season.

\subsection{Evaluation of Irrigation Water Quality with Respect to Different Standards}

The water quality parameters of Shailmari River and its connected channel were compared with the standards set by the Department of Environment (DoE), Bangladesh [56] and also with the usual range of irrigation water quality parameters founded by FAO [3]. The results of the evaluation are incorporate in Table 6 and it shows that, in pre-monsoon, only the values of $\mathrm{HCO}_{3}^{-}, \mathrm{K}^{+}, \mathrm{pH}$ and $\mathrm{Ca}^{2+}$ are within the acceptable limit of irrigation according to the $\mathrm{FAO}$ [3] and Bangladesh [56] standards whereas rest of the parameters do not comply the standards during this season. However, in monsoon and in post-monsoon, all of the parameters like acid/basicity $(\mathrm{pH})$, Electrical conductivity of water (EC), Sodium Adsorption Ratio (SAR), $\mathrm{Ca}^{2+}, \mathrm{Mg}^{2+}, \mathrm{Na}^{+}, \mathrm{HCO}_{3}^{-}$, $\mathrm{SO}_{4}^{2-}$ and the nutrients such as $\mathrm{NO}_{3}^{-}-\mathrm{N}$, and $\mathrm{K}^{+}$of water of the Shailmari River system were within the usual range determined by FAO [3]. Therefore, it can be assumed that the river water becomes usable for crop irrigation during these two agricultural seasons.

Table 6. Quality evaluation of irrigation water with respect to FAO and DoE Standards.

\begin{tabular}{|c|c|c|c|c|c|c|c|c|c|c|}
\hline \multirow{3}{*}{ Categories } & \multirow{3}{*}{ Parameter } & \multirow{3}{*}{ Unit } & \multirow{3}{*}{$\mathrm{FAO}^{1}$} & \multirow{3}{*}{$\operatorname{DoE}^{2}$} & \multicolumn{6}{|c|}{ Percentage (\%) of samples } \\
\hline & & & & & \multicolumn{2}{|c|}{ Pre-monsoon } & \multicolumn{2}{|c|}{ Monsoon } & \multicolumn{2}{|c|}{ Post-monsoon } \\
\hline & & & & & Within & Beyond & Within & Beyond & Within & Beyond \\
\hline \multirow{2}{*}{ Salinity } & EC & $\mu \mathrm{S} / \mathrm{cm}$ & $0-3000$ & 2250 & & 100 & 100 & & 100 & \\
\hline & TDS & $\mathrm{mg} / \mathrm{L}$ & $0-2000$ & 2100 & & 100 & 100 & & 100 & \\
\hline \multirow{6}{*}{$\begin{array}{c}\text { Cations and } \\
\text { Anions }\end{array}$} & $\mathrm{Ca}^{2+}$ & meq/l & $0-20$ & & 95.5 & 4.5 & 100 & & 100 & \\
\hline & $\mathrm{Mg}^{2+}$ & $\mathrm{meq} / \mathrm{l}$ & $0-05$ & & & 100 & 100 & & 100 & \\
\hline & $\mathrm{Na}^{+}$ & meq/l & $0-40$ & 43.5 & & 100 & 100 & & 100 & \\
\hline & $\mathrm{HCO}_{3}^{-}$ & meq/l & $0-10$ & & 100 & & 100 & & 100 & \\
\hline & $\mathrm{Cl}^{-}$ & meq/l & $0-30$ & & & 100 & 100 & & 100 & \\
\hline & $\mathrm{SO}_{4}^{2-}$ & $\mathrm{meq} / \mathrm{l}$ & $0-20$ & & & 100 & 100 & & 100 & \\
\hline \multirow{2}{*}{ Nutrients } & $\mathrm{NO}_{3}-\mathrm{N}$ & $\mathrm{mg} / \mathrm{l}$ & $0-10$ & 10 & & 100 & 100 & & 100 & \\
\hline & $\mathrm{K}^{+}$ & meq/l & $0-20$ & & 100 & & 100 & & 100 & \\
\hline \multirow{2}{*}{ Other } & $\mathrm{pH}$ & $1-14$ & $6.0-8.5$ & $6.5-8.5$ & 100 & & 100 & & 100 & \\
\hline & SAR & $\mathrm{meq} / \mathrm{l}$ & $0-15$ & 23 & & 100 & 100 & & 100 & \\
\hline
\end{tabular}

${ }^{1}[3],{ }^{2}[56]$. 


\subsection{Water Quality Evaluation from Graphical Representation}

The US Salinity Laboratory Staff (USSL) diagram, also known as SAR-Conductivity plot diagram is a widely used graphical method to classify and evaluate the water quality of riverfor irrigation purpose. The diagram reflects the integrated effect of EC and SAR, plotting EC (as salinity hazard) against SAR (as alkalinity hazard) [29] [57]. The USSL diagram (Figure 4) of the present study shows that, about $100 \%$ of the river water samples in pre-monsoon lie in the class of C4-S4 indicating very high salinity- very high sodium hazard water. Very high sodium water with high EC affects the plant growth directly by limiting the water and nutrient capacity and also affect the soil structure that leads to soil degradation [49] [58]. Therefore, the water of the Shailmari River and adjacent channel in the pre-monsoon is regarded as unsuitable for irrigation which restricts the use of the river water for irrigation during this season [52]. Most of the samples of monsoon and post-monsoon, fall within the classes of C1-S1 (low salinity with low sodium) and C2-S1 (medium salinity with low sodium), which indicates

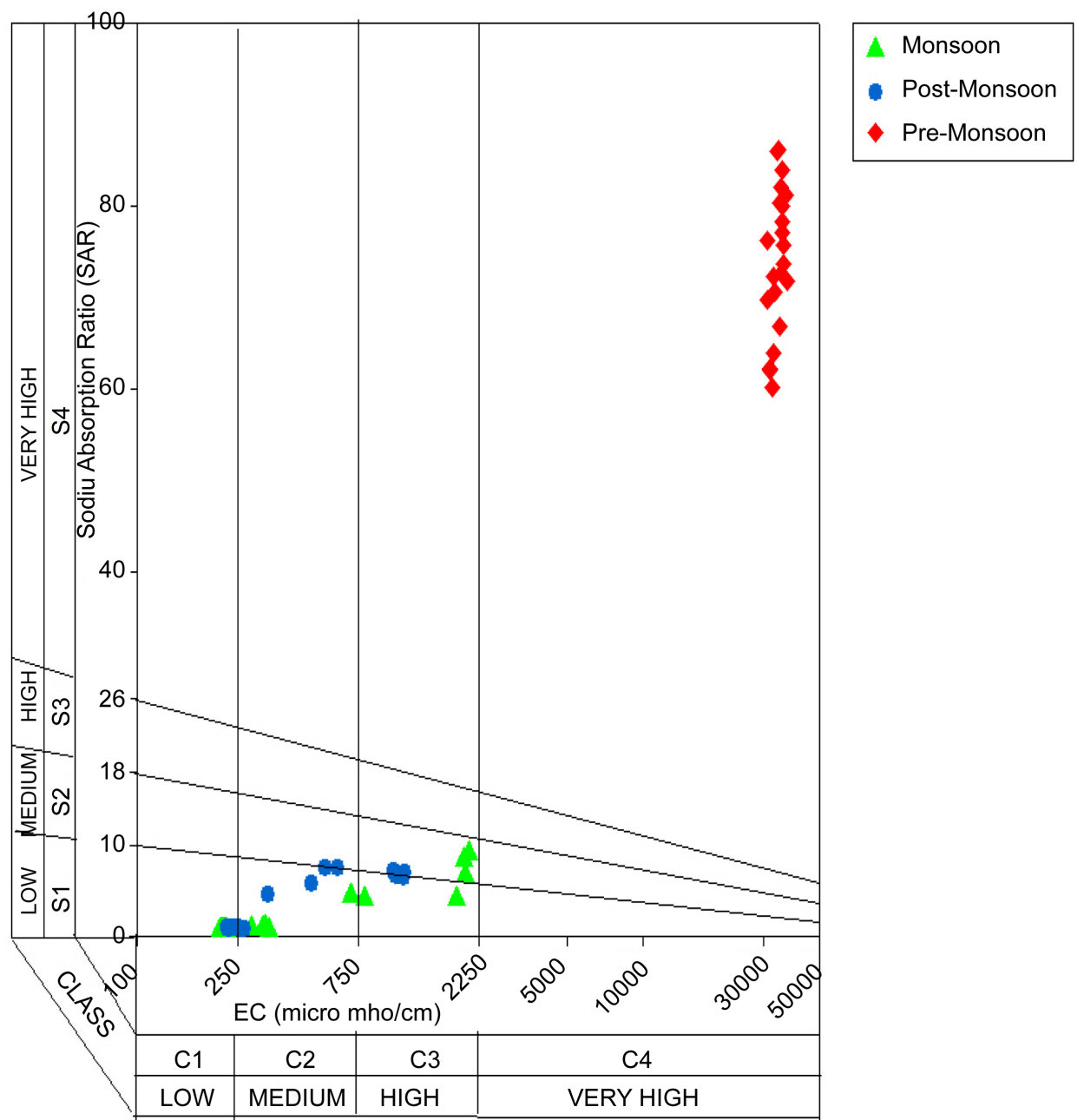

Figure 4. US salinity laboratorydiagram for classification of irrigation waters (after Richards, 1954). 
that water can be used for irrigating the crops in most of the soils with very less danger [30]. A small number of samples of monsoon (9\%) fall into the C3-S1 (high salinity with low sodium) class, while $13.64 \%$ of monsoon and $9 \%$ of post-monsoon samples lie within the class of C3-S2 (high salinity with medium sodium). High salinity affects the plant growth, while medium sodium water pose sodium hazard in fine-textured soils. Therefore, use of high saline water is quite unsuitable for crop irrigation or could be used with special soil management practices during irrigation [52].

Wilcox diagram was also used to investigate the suitability of the water for irrigation by plotting the sodium percentage $(\% \mathrm{Na})$ against electrical conductivity (EC) [8]. Figure 5 depicts that, regardless of the sampling locations and tidal variation all of the samples of pre-monsoon are "unsuitable" for use in irrigation. It also illustrates that most of the samples of monsoon and post-monsoon are within the "excellent to good" and "good to permissible" classes whereas $9.1 \%$ of monsoon and $31.8 \%$ of post-monsoon water samples fall into the "permissible to doubtful" class. Therefore, it can be speculated that the water of the river system can be used for irrigation in most cases without prior special soil management practices during monsoon and post-monsoon. However, the water becomes highly saline with maximum load of sodium ions during pre-monsoon which restricts the use of river water for irrigation in this season. This also infers the necessity of replacing the irrigation system with harvested rainwater or use of treated wastewater as irrigation water in the crop fields as groundwater is prone to saline and fresh water is scarce in this region during this dry season (pre-monsoon), while over extraction of deep aquifer water for irrigation might make this resource more vulnerable. Besides, development and cultivation of saline tolerant varieties of different crops with good soil drainage and management practices would give a better solution to this problem of the study area during the dry pre-monsoon period.

\section{Conclusion}

The results of the study on the irrigation water quality of the Shailmari River and its adjacent channel clearly demonstrate that the hydrochemistry of the river system is highly variable to the seasonal changes and therefore, the water quality also. In premonsoon, the river water is highly concentrated with major ions that exhibit high salinity (high EC). $\mathrm{Na}^{+}$and $\mathrm{Cl}^{-}$dominate the major cationic and anionic chemistry in premonsoon, showing an order of $\mathrm{Na}^{+}>\mathrm{Mg}^{2+}>\mathrm{Ca}^{2+}>\mathrm{K}^{+}$and $\mathrm{Cl}^{-}>\mathrm{SO}_{4}^{2-}>\mathrm{HCO}_{3}^{-}>$ $\mathrm{NO}_{3}^{-}>\mathrm{PO}_{4}^{3-}$ accordingly. Higher load of the ions may be attributed to the sea water mixing coupled with limited freshwater inflow, wreathing inputs and anthropogenic discharges into the water bodies. Monsoon and post-monsoon precipitation imposes a freshening effect (dilution) on the river water chemistry that leads to reorder the ionic pattern of the river water in these seasons. The cationic order of $\mathrm{Ca}^{2+}>\mathrm{Na}^{+}>\mathrm{Mg}^{2+}>\mathrm{K}^{+}$ and $\mathrm{Na}^{+}>\mathrm{Ca}^{2+}>\mathrm{Mg}^{2+}>\mathrm{K}^{+}$was found in monsoon and post-monsoon respectively, while the anions showed an order of $\mathrm{HCO}_{3}^{-}>\mathrm{Cl}^{-}>\mathrm{SO}_{4}^{2-}>\mathrm{NO}_{3}^{-}>\mathrm{PO}_{4}^{3-}$ and $\mathrm{HCO}_{3}^{-}>\mathrm{SO}_{4}^{2-}>\mathrm{Cl}^{-}>\mathrm{NO}_{3}^{-}>\mathrm{PO}_{4}^{3-}$ in the consecutive sampling seasons. During pre-monsoon, the river water is $\mathrm{Na}-\mathrm{Cl}$ type, while in monsoon and post-monsoon 


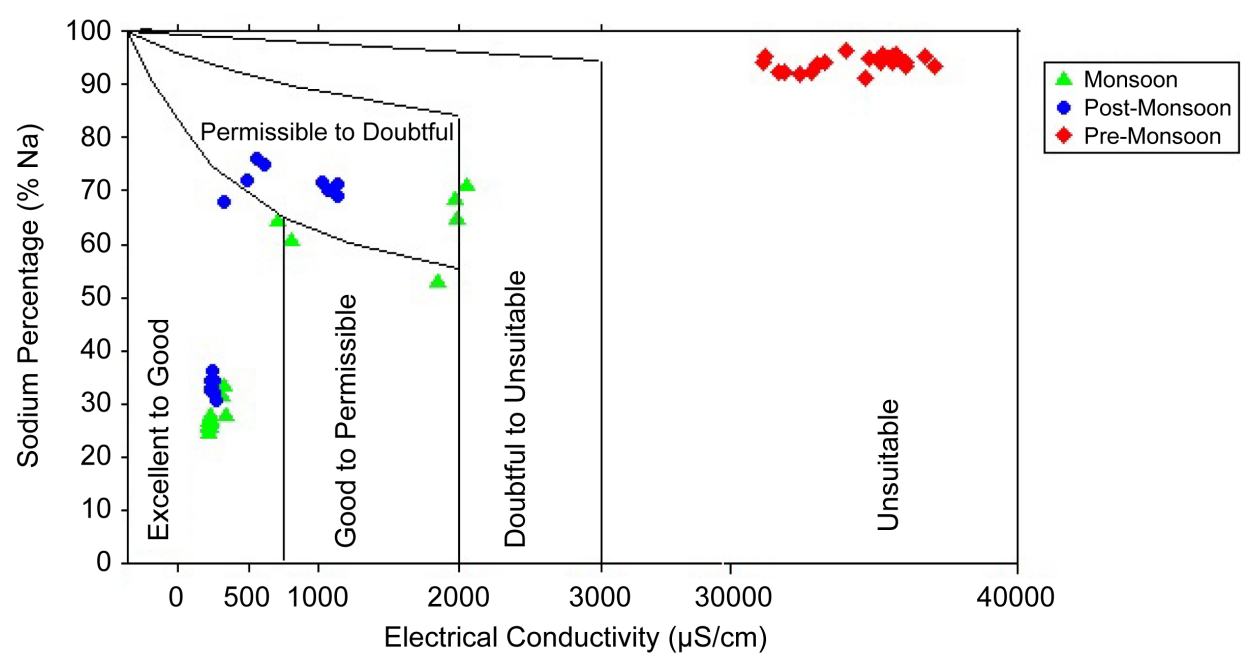

Figure 5. Plot of sodium percentage versus electrical conductivity for classification of Shailmari River water (after Wilcox, 1948).

the water becomes $\mathrm{Ca}-\mathrm{Mg}-\mathrm{Na}-\mathrm{HCO}_{3}$ and $\mathrm{Ca}-\mathrm{Na}-\mathrm{Mg}-\mathrm{HCO}_{3}$ type, respectively, showing temporary hardness. Irrigational suitability of the river water in terms of calculated values of SAR, \%Na, RSC, PI, KI and $\mathrm{MH}$ together with TDS, $\mathrm{NO}_{3}-\mathrm{N}$ and $\mathrm{pH}$ classes was assessed for the three sampling seasons which restricted the use of the river water for irrigation in pre-monsoon. The values were found within the limits of suitability for irrigating the crops during rest of the two agricultural seasons. However, higher KI and $\mathrm{MH}$ values with high salinity make it doubtful to use the channel water even in the monsoon and post-monsoon seasons. USSL and Wilcox diagrams were applied to verify the results and found the river water unsuitable for use in pre-monsoon, complying with the results extracted from the calculated parameters for this and also other studied seasons. This river system supports the regional agricultural production of this area and plays a pivotal role in the livelihood of a large number of people dependent on the agricultural production. Use of high saline and sodic water in the early monsoon might deteriorate the soil fertility and the agricultural production in the long run. Besides, domestic and industrial waste and wastewater discharges adversely affect the water chemistry of the river system that in turn degrades the irrigation water quality, posing a potential menace to the agricultural communities. Therefore, from the study it could be concluded that proper water management strategies with inclusion of long-term river water quality monitoring, awareness building against waste dumping, finding alternative sources and efficient methods for irrigation would ensure the sustainable agricultural production of this locality and this study would be the basis of future studies for such purposes.

\section{Acknowledgements}

This study was supported by the University Grants Commission (UGC) of Bangladesh under the project entitled "Assessment and Evaluation of the Natural Waters Suitability for Irrigation in and around Shalimari River, Khulna". The authors gratefully ac- 
knowledge the Environmental Science Discipline and Chemistry Discipline of Khulna University, Bangladesh for providing all sorts of support during laboratory analysis.

\section{References}

[1] Dang, T., Tsujimura, M., Le, V., Kawachi, A. and Thu, D. (2014) Chemical Characteristics of Surface Water and Groundwater in Coastal Watershed, Mekong Delta, Vietnam. Procedia Environmental Sciences, 20, 712-721. http://dx.doi.org/10.1016/j.proenv.2014.03.085

[2] Vyas, A. and Jethoo, A.S. (2015) Diversification in Measurement Methods for Determination of Irrigation Water Quality Parameters. Aquatic Procedia, 4, 1220-1226. http://dx.doi.org/10.1016/j.aqpro.2015.02.155

[3] Ayers, R.S. and Westcot, D.W. (1985) Water Quality for Agriculture. FAO Irrigation and Drainage Paper 29 Rev. 1, FAO, Rome.

[4] Simsek, C. and Gunduz, O. (2007) IWQ Index: A GIS-Integrated Technique to Assess Irrigation Water Quality. Environmental Monitoring and Assessment, 128, 277-300. http://dx.doi.org/10.1007/s10661-006-9312-8

[5] Sappa, G., Ergul, S., Ferranti, F., Ngalya, L. and Luciani, G. (2015) Effects of Seasonal Change and Seawater Intrusion on Water Quality for Drinking and Irrigation Purposes, in Coastal Aquifers of Dar es Salaam, Tanzania. Journal of African Earth Sciences, 105, 64-84. http://dx.doi.org/10.1016/j.jafrearsci.2015.02.007

[6] Maas, E.V. and Tanjii, K.K. (1990) Agricultural Salinity Assessment and Management. ASCE Manuals Reports Eng. Pract., No. 71, 262-304.

[7] Kwiatkowski, J., Marciak, L.C., Wentz, D. and King, C.R. (1995) Salinity Mapping for Resource Management within the County of Wheatland, Alberta. Conservation and Development Branch, Alberta Agriculture, Food and Rural Development, Edmonton.

[8] Wilcox, L.V. (1948) The Quality of Water for Irrigation Use. TechReport.

[9] Shahid, S., Chen, X. and Hazarika, M.K. (2006) Evaluation of Groundwater Quality for Irrigation in Bangladesh Using Geographic Information System. Journal of Hydrology and Hydromechanics, 54, 3-14.

[10] Hasan, K.F., Khaleque, M., Shahjahan, M. and Haque, M.A. (2007) Water Quality for Irrigation, Emphasis on Arsenic Contamination in Agriculture, 2004-2007.

[11] Rahman, M., Das, R., Hassan, N. and Roy, K. (2014) Environmental Study on Water Quality of Mayur River with Reference to Suitability for Irrigation. International Journal of Environmental Sciences, 4, 1150-1167.

[12] FAO (2011) Irrigation in Southern and Eastern Asia in Figures. Rome, Itay.

[13] Mondal, M.S., Jalal, M.R., Khan, M.S.A., Kumar, U., Rahman, R. and Huq, H. (2013) Hydro-Meteorological Trends in Southwest Coastal Bangladesh: Perspectives of Climate Change and Human Interventions. American Journal of Climate Change, 2, 62-70. http://dx.doi.org/10.4236/ajcc.2013.21007

[14] Gain, A.K. and Giupponi, C. (2014) Impact of the Farakka Dam on Thresholds of the Hydrologic: Flow Regime in the Lower Ganges River Basin (Bangladesh). Water, 6, 2501-2518. http://dx.doi.org/10.3390/w6082501

[15] Karim, Z., Hussain, S.G. and Ahmed, M. (1990) Salinity Problems and Crop Intensification in the Coastal Regions of Bangladesh. Soils Publication No. 33, 1-20.

[16] Bahar, M.M. and Reza, M.S. (2010) Hydrochemical Characteristics and Quality Assessment of Shallow Groundwater in a Coastal Area of Southwest Bangladesh. Environmental Earth 
Sciences, 61, 1065-1073. http://dx.doi.org/10.1007/s12665-009-0427-4

[17] Mondal, M.K., Tuong, T.P., Ritu, S.P., Choudhury, M.H.K., Chasi, A.M., Majumder, P.K., Islam, M.M. and Adhikary, S.K. (2006) Coastal Water Resource Use for Higher Productivity: Participatory Research for Increasing Cropping Intensity in Bangladesh. In: Hoanh, C.T., Tuong, T.P., Gowing, J.W. and Hardy, B., Eds., Environment and Livelihoods in Tropical Coastal Zones. Managing Agriculture-Fishery-Aquaculture Conflicts, CABI Publishing, London, 72-85. http://dx.doi.org/10.1079/9781845931070.0072

[18] Adhikari, D.K., Roy, M.K., Datta, D.K., Roy, P.J., Roy, D.K., Malik, A.R. and Alam, A.K.M.B. (2006) Urban Geology: A Case Study of Khulna City Corporation, Bangladesh. Journal of Life and Earth Science, 1, 17-29.

[19] Roy, M.K., Datta, D.K., Adhikari, D.K., Chowdhury, B.K. and Roy, P.J. (2005) Geology of the Khulna City Corporation. Journal of Life and Earth Science, 1, 57-63.

[20] APHA (1999) Standard Methods for the Examination of Water and Wastewater. Standard Methods, 541.

[21] Huang, J., Huang, Y. and Zhang, Z. (2014) Coupled Effects of Natural and Anthropogenic Controls on Seasonal and Spatial Variations of River Water Quality during Baseflow in a Coastal Watershed of Southeast China. PLOS ONE, 9, e91528. http://dx.doi.org/10.1371/journal.pone.0091528

[22] Ramesh, R. and Anbu, M. (1996) Chemical Methods for Environmental Analysis: Water and Sediment. Macmillan Publishers, London.

[23] Hounslow, A. (1995) Water Quality Data: Analysis and Interpretation. CRC Press, Boca Raton.

[24] Voutsa, D., Manoli, E., Samara, C., Sofoniou, M. and Stratis, I. (2001) A Study of Surface Water Quality in Macedonia, Greece: Speciation of Nitrogen and Phosphorus. Water, Air, and Soil Pollution, 129, 13-32. http://dx.doi.org/10.1023/A:1010315608905

[25] Sawyer, C.N. and McCarty, P.L. (1967) Chemistry for Sanitary Engineers. McGraw-Hill, New York.

[26] Davis, S.N. and De Wiest, R.J. (1966) Hydrogeology. Wiley, New York.

[27] Freeze, R.A. and Cherry, J.A. (1979) Groundwater. Prentice-Hall Inc., Englewood Cliffs, Vol. 7632, 604 .

[28] Subramani, T., Elango, L. and Damodarasamy, S.R. (2005) Groundwater Quality and Its Suitability for Drinking and Agricultural Use in Chithar River Basin, Tamil Nadu, India. Environmental Geology, 47, 1099-1110. http://dx.doi.org/10.1007/s00254-005-1243-0

[29] Sundaray, S.K., Nayak, B.B. and Bhatta, D. (2009) Environmental Studies on River Water Quality with Reference to Suitability for Agricultural Purposes: Mahanadi River Estuarine System, India-A Case Study. Environmental Monitoring and Assessment, 155, 227-243. http://dx.doi.org/10.1007/s10661-008-0431-2

[30] Singh, A.K., Mondal, G.C., Kumar, S., Singh, T.B., Tewary, B.K. and Sinha, A. (2008) Major Ion Chemistry, Weathering Processes and Water Quality Assessment in Upper Catchment of Damodar River Basin, India. Environmental Geology, 54, 745-758. http://dx.doi.org/10.1007/s00254-007-0860-1

[31] Doneen, L.D. (1964) Notes on Water Quality in Agriculture. Department of Water Science and Engineering, University of California, Davis.

[32] Piper, A.M. (1944) A Graphic Procedure in the Geochemical Interpretation of WaterAnalyses. Eos, Transactions American Geophysical Union, 25, 914-928.

http://dx.doi.org/10.1029/TR025i006p00914 
[33] USLS (USLL) (1954) Diagnosis and Improvement of Saline and Alkali Soils. Agriculture Handbook No. 60, US Department of Agriculture (USDA), Washington DC.

[34] Richards, L.A. (1954) Diagnosis and Improvement of Saline and Alkali Soils. Soil Science, 78, 154. http://dx.doi.org/10.1097/00010694-195408000-00012

[35] Apha, L.S., Clesceri, A.E. and Greenberg, A.D. (1998) Standard Methods for the Examination of Water and Wastewater. 20th Edition, American Water Works Association, Washington DC.

[36] Kelley, W.P. (1963) Use of Saline Irrigation Water. Soil Science, 95, 385-391. http://dx.doi.org/10.1097/00010694-196306000-00003

[37] Szabolcs, I. and Darab, C. (1964) The Influence of Irrigation Water of High Sodium Carbonate Content of Soils. Proceedings of 8 th International Congress of ISSS, 2, 803-812.

[38] Pekey, H., Karakaş, D. and Bakoglu, M. (2004) Source Apportionment of Trace Metals in Surface Waters of a Polluted Stream Using Multivariate Statistical Analyses. Marine Pollution Bulletin, 49, 809-818. http://dx.doi.org/10.1016/j.marpolbul.2004.06.029

[39] Gain, A.K., Uddin, M.N. and Sana, P. (2008) Impact of River Salinity on Fish Diversity in the South-West Coastal Region of Bangladesh. International Journal of Environmental Science and Technology, 34, 49-54.

[40] Datta, D.K. and Subramanian, V. (1997) Nature of Solute Loads in the Rivers of the Bengal Drainage Basin, Bangladesh. Journal of Hydrology, 198, 196-208. http://dx.doi.org/10.1016/S0022-1694(96)03294-5

[41] Li, S. and Zhang, Q. (2009) Geochemistry of the Upper Han River Basin, Chapter 2: Seasonal Variations in Major Ion Compositions and Contribution of Precipitation Chemistry to the Dissolved Load. Journal of Hazardous Materials, 170, 605-611. http://dx.doi.org/10.1016/j.jhazmat.2009.05.022

[42] Bu, H., Tan, X., Li, S. and Zhang, Q. (2010) Temporal and Spatial Variations of Water Quality in the Jinshui River of the South Qinling Mts., China. Ecotoxicology and Environmental Safety, 73, 907-913. http://dx.doi.org/10.1016/j.ecoenv.2009.11.007

[43] Appelo, C.A.J. and Postma, D. (2010) Geochemistry, Groundwater and Pollution. 2nd Edition, CRC Press, Boca Raton, Vol. 32, No. 2.

[44] Varol, M., Gökot, B., Bekleyen, A. and Şen, B. (2012) Spatial and Temporal Variations in Surface Water Quality of the Dam Reservoirs in the Tigris River Basin, Turkey. Catena, 92, 11-21. http://dx.doi.org/10.1016/j.catena.2011.11.013

[45] Deo, N. and Ali, M. (1993) Water Quality of a Mining Area in Keonjhar District for Drinking and Agriculture. Indian Journal of Environmental Protection, 13, 652-658.

[46] Raghunath, H.M. (1987) Groundwater. Wiley Eastern Ltd., Delhi, 563.

[47] Eaton, F.M. (1950) Significance of Carbonates in Irrigation Waters. Soil Science, 69, 123134. http://dx.doi.org/10.1097/00010694-195002000-00004

[48] Tiwari, T.N. and Manzoor, A. (1988) River Pollution in Kathmandu Valley (Nepal) Suitability of River Water for Irrigation. Indian Journal of Environmental Protection, 8, 269274.

[49] Todd, D.K. and Mays, L.W. (1980) Groundwater Hydrology. Wiley, Hoboken.

[50] Domenico, P.A. and Schwartz, F.W. (1990) Physical and Chemical Hydrogeology. John Wiley and Sons, New York.

[51] Nagarajan, R., Rajmohan, N., Mahendran, U. and Senthamilkumar, S. (2010) Evaluation of Groundwater Quality and Its Suitability for Drinking and Agricultural Use in Thanjavur city, Tamil Nadu, India. Environmental Monitoring and Assessment, 171, 289-308. 
http://dx.doi.org/10.1007/s10661-009-1279-9

[52] Haritash, A.K., Kaushik, C.P., Kaushik, A., Kansal, A. and Yadav, A.K. (2008) Suitability Assessment of Groundwater for Drinking, Irrigation and Industrial Use in Some North Indian Villages. Environmental Monitoring and Assessment, 145, 397-406.

http://dx.doi.org/10.1007/s10661-007-0048-x

[53] Rahman, M.M., Hassan, M.Q., Islam, M.S. and Shamsad, S.Z.K.M. (2000) Environmental Impact Assessment on Water Quality Deterioration Caused by the Decreased Ganges Outflow and Saline Water Intrusion in South-Western Bangladesh. Environmental Geology, 40, 31-40. http://dx.doi.org/10.1007/s002540000152

[54] Maas, E.V. (1990) Crop Salt Tolerance. In: Tanji, K., Ed., Agricultural Salinity Assessment and Management, ASCE Manuals \& Reports on Engineering Practice No. 71, ASCE, 262304.

[55] Paliwal, K.V. and Singh, S. (1967) Effect of Gypsum Application on the Quality of Irrigation Waters. Madras Agricultural Journal, 59, 646-647.

[56] DoE (1997) The Environment Conservation Rules 1997. Ministry of Environment and Forest, Dhaka, 1324-1327.

[57] Richards, L.A. (1954) Diagnosis and Improvement of Saline and Alkali Soils. US Salinity Laboratory Staff, US Department of Agriculture, Washington DC.

[58] Dhanasekarapandian, M., Chandran, S., Devi, D.S. and Kumar, V. (2016) Spatial and Temporal Variation of Groundwater Quality and Its Suitability for Irrigation and Drinking Purpose Using GIS and WQI in an Urban Fringe. Journal of African Earth Sciences.

\section{Submit or recommend next manuscript to SCIRP and we will provide best service for you:}

Accepting pre-submission inquiries through Email, Facebook, LinkedIn, Twitter, etc. A wide selection of journals (inclusive of 9 subjects, more than 200 journals)

Providing 24-hour high-quality service

User-friendly online submission system

Fair and swift peer-review system

Efficient typesetting and proofreading procedure

Display of the result of downloads and visits, as well as the number of cited articles

Maximum dissemination of your research work

Submit your manuscript at: http://papersubmission.scirp.org/

Or contact gep@scirp.org 